\title{
CONTRIBUTION OF THE URBAN POOR: EVIDENCE FROM CHENNAI, INDIA
}

\author{
Kala Seetharam Sridhar and A. Venugopala Reddy*
}

In the present paper, evidence is gathered on the contribution of the poor to the city economy, using the case of Chennai in India based on large primary surveys. We find that gender, education level and the salary status of the urban poor have a significant impact on their income. The paper takes into account the contribution made by informal enterprises located in the slums of the city. By aggregating across households and enterprises based on the primary surveys and extending this contribution to all slums in the city, we find that slums, which contain 19 per cent of the population of Chennai, contribute to 14 per cent of the city's economy. The paper summarizes the policy implications of the research.

JEL Classification: I32, J31, 015, 018.

Key words: Urban poor, cities — India, contribution of urban poor, urban poverty — Chennai.

- Kala Seetharam Sridhar, Professor, Centre for Research in Urban Affairs, Institute for Social and Economic Change, Dr. VKRV Rao Road, Nagarabhavi, Bengaluru 560072, India, corresponding author, (Tel: +91-80-23210106 (direct); e-mail: kala@isec.ac.in, kala_sridhar2002@yahoo.com, kalaseetharam @gmail.com); A.Venugopala Reddy, Centre for Symbiosis of Technology, Environment and Management (STEM), 11 \& 12, 1st Floor, BDA Complex, Koramangala, Bengaluru 560034, India (Tel: +91-9448310808; e-mail: avgreddy@gmail.com). We thank the South Asia Network of Economic Research Institutes (SANEI) for funding this important idea to roll out in Chennai as part of its $13^{\text {th }}$ Regional Research Competition (RRC), when we were both with Public Affairs Centre. Special thanks are due to Samuel Paul for his suggestions, which have substantially added to the value of this work. We are grateful to Dr. Sreedharan of the Public Affairs Centre, who patiently monitored and supervised the surveys by personally visiting the slums in Chennai. We thank Nivedita Kashyap, who provided assistance during various stages of the study. We thank Tamil Nadu's Secretary, Housing and Urban Development, for extending his support to the study. Thanks are due to the Tamil Nadu Slum Clearance Board for giving us a map of the Chennai slums, and their population. We thank the survey team, primarily Suseela Anand and Vijai Anand, for coordinating the efforts of the survey team to successfully finish them before the specified deadline. Thanks are due to the survey team for diligently completing the surveys, for following our detailed instructions. Our thanks are due to Gnaneshwar, the data entry operator, who patiently checked and entered the data. Thanks are due to the team at Public Affairs Centre for their logistic support of the study. We are thankful to the two anonymous reviewers and the editor of this manuscript for their comments, which have enhanced the value of the findings here. Any errors remain ours. 


\section{INTRODUCTION}

Given that India is rapidly growing and urbanizing, and that it has more than 7,000 towns, which are going to soon become politically influential and contribute to nearly 65 per cent of gross domestic product (GDP), it is crucial to understand urban poverty in the country. ${ }^{1}$ While cities offer opportunities, such as jobs, and the possibility of networking and interactions to the poor, they also induce the conditions within which poverty spreads. On the positive side, it is well known that urban development leading to economic growth (and greater economic growth leading to increased urbanization) increases the income of the poor. Cities have the capability to improve living and working conditions, and to create an environment within which poor people are treated equitably by political and bureaucratic systems. Unfortunately, however, many poor do not benefit from the opportunities offered by cities (www.dfid.gov.uk/Documents/publications/wssd-neg-cochin.pdf).

Throughout the world, urban poverty is rising; in certain countries, the urban poor are growing at a more rapid rate than the rural poor. India is no exception. Urban poverty in India remains high, at roughly 25 per cent, with an estimated 80 million poor people in the cities and towns of India (source: National Sample Survey Organization's survey report). An example of the magnitude of this problem: 80 million is roughly equal to the population of Egypt. The rising number of poor living in urban areas has resulted in a phenomenon called the "urbanization of poverty". The scale of the problem in India means that any work done to understand urban poverty and its contribution has implications for an international audience.

\section{Research questions and core research objectives}

In the present paper, evidence on the contribution of the urban poor to their urban economies is reported. This information could potentially add strength to their voices in the policymaking process. The paper also attempts to quantify different dimensions of the contribution of the urban poor to the urban economy. Specifically, this paper endeavours to answer the following questions:

Poverty is defined differently in different countries of the world. The Planning Commission in India defines the number and proportion of population living below the poverty line based on the recommendations of a Taskforce on the Projection of Minimum Needs and Effective Consumption Demands (1979). This Taskforce defines the poverty line as the cost of obtaining an all India consumption basket that meets the following caloric norms: 2,100 calories per person per day in the urban areas and 2,400 calories in the rural areas. These norms translate into 49.09 Indian rupees (Rs) (US\$0.77, based on the exchange rate of US\$1 = INR63.85, as per the Reserve Bank of India's website (www.rbi.org.in/ on 19 June 2015) for rural areas and Rs56.64 per capita per month (US\$0.89) for urban areas (all in 1973/74 prices). This converts to Rs351.86 per month for rural areas (US\$5.5) and Rs547.42 per month for urban areas (US\$8.6) as of 2004/05. Available from www.scribd.com/doc/2336001/Measuring-Urban-Povertyin-India. 
1. How do the urban poor contribute to the city's economy? What is their role in the urban economy's structure consisting of labour and manufacturing (enterprises in the economy)? Can a value be placed on their service support to the urban middle and upper classes, which enables that group to engage in economic activities that increase the wealth of the city they live in? Are the urban poor primarily entrepreneurial (self-employed) or employed by others. This will help shed light on the contributions low income areas make to the city's entrepreneurship. This paper also makes an attempt to understand the demographic and income earning characteristics of the urban poor. It examines if the sociodemographic and other characteristics of the urban poor determine their contribution to the city's economy, society and governance.

2. What is the contribution of the urban poor to savings? Here their investment in their housing and other assets, and impacts on their remittances will be studied.

This paper is organized as follows. First, a literature review to document that this is really unchartered territory is presented. Then, the methodology adopted to perform the research is summarized. Following the description of the methodology, the primary findings from the surveys are summarized. This is done by first presenting the findings from the household surveys, responding to the various hypotheses raised, and then disclosing the regressions, which summarize the determinants of the contribution of the urban poor to the economy. The next section discusses the inequalities between the slum and non-slum economy of Chennai, based on secondary data. Then, the findings from the survey of enterprises are summarized. Following this, a section pulls together the contribution of the urban poor based on the households and the enterprises, after which the final section contains a summary of the policy implications of the research and the conclusion.

\section{LITERATURE REVIEW}

Two broad approaches have been used in the literature to understand the contribution of the urban poor. In one approach, the poor are viewed at the aggregate, place-based level for their contributions to the urban economy. In this approach, attempts are made to understand the contribution of low income areas (rather than the residents themselves) to the city economy. In the search of the literature, it was found that Frankenhoff (1967) and Ulack (1978) focus on this approach. In another more micro approach, the urban poor (rather than the area where they live) are viewed as contributors to the national economy. More recent literature (for example, Hayami, Dikshit and Mishra, 2006) focuses on this micro approach. Some equate the urban 
poor with those in the informal sector. The informal sector is economic activity that is neither taxed nor monitored by a government, and is not included in the country's gross national product (GNP), as opposed to a formal economy. Although the informal economy is often associated with developing countries - where up to 60 per cent of the labour force (with as much 40 per cent of GDP) work (Miller, 2013), all economic systems contain an informal economy in some proportion. The informal economy in developing countries is diverse; it usually includes small-scale, as well as larger, regular enterprises and occasional members (often street vendors and garbage recyclers).

In addition, during the course of the research, studies that attempt to estimate the contribution of the informal sector to the economy (see Sinha, Sangeeta and Siddiqui, 1999) are reviewed. Against the backdrop and inability of the formal sector to provide adequate employment to job seekers, Olajoke and others (2013) seek to examine the role of urban informal enterprises as an alternative to job provision in the Ibadan cosmopolitan region, and find that a large proportion of respondents agree that it provides jobs, is perceived to increase the income of operators, especially those that engage in it to sustain their livelihood, and prevents youth from indulging in criminal activities. The authors recommend that the government formalize urban informal enterprises by institutionalizing them through proper registration, easy access to loans and other available financial assistance.

Furthermore, generally in India, most of the urban poor are involved in the informal sector activities in which there is constant threat of eviction, removal, confiscation of goods and almost non-existent social security cover. While most informal sector workers are poor, not all urban poor work in the informal sector. Hence, the research is not confined to the informal sector, but it also takes into account all urban poor.

While reviewing the literature, it was noted that empirical evidence regarding the above was quite limited in the context of urban poor in cities of developing countries, such as India. This was what is attempted in this research as the role of the urban poor and low-income areas in urban growth differs substantially between the developed and the developing economies. The India Urban Poverty Report (India, Ministry of Housing and Urban Poverty Alleviation, 2009) is noted, but there are no specific data which point to this. It was also found during the review that in this literature, no data that relate to the contribution made by the urban poor in the cities of India exists. Sridhar and Reddy (2014) estimate the contribution of the urban poor to the city economy of Bengaluru, this paper assesses the same for Chennai. 


\section{METHODOLOGY}

Defining the category of the "urban poor" is not a straightforward task. However, given the limitations of the information available, for this paper, it is assumed that slum dwellers represent the poor of the city. As per Gupta, Arnold and Lhungdim (2009), 63 per cent of the population of Chennai were living outside of the census-designated slums. The challenge is to geographically map such information.

It may be noted that income-based poverty line estimates and targeting of families below the poverty line (BPL), have proved especially controversial (see Vakulabharanam and Motiram, 2012). However, it must be noted that the "poor" are best seen as a highly heterogeneous group, occupying different niches within the urban economy.

It should also be mentioned that this paper does not assess the value addition created by the poor through the provision of certain essential services or by cost savings on activities that the government may have to undertake otherwise, which Hayami, Dikshit and Mishra (2006) estimate. Nor does it follow the methodology of Hayami, Dikshit and Mishra (2006), which assess the reduction in the expenditure of the government of Municipal Corporation of New Delhi, because of the work of ragpickers. Alternatively, this paper assesses the contribution made by the urban poor to the economy of Chennai, using primary surveys of the slum dwellers in the city, utilizing certain unique data sets, which throw light on the city economy's size and the use of standard national income accounting methods.

Given the limitations of time and budget, Chennai was selected for studying the research questions discussed in this paper. Secondary data on the geographic location of the slums from the Tamil Nadu Slum Clearance Board were gathered. Thus, it should be noted that this paper takes a spatial approach to defining the urban poor. As finding reliable demographic data for each low income area is difficult, data regarding various aspects of the contribution of the urban poor through primary surveys of the urban poor were gathered. The poor families of Chennai constitute 14 per cent of the city's households (Sridhar and Kashyap, 2014), ${ }^{2}$ consistent with the India Urban Poverty Report (India, Ministry of Housing and Urban Poverty Alleviation, 2009), which estimates the percentage of poor in large cities to be 14 per cent, as of 1999/2000. Given the data constraints, a representative group of such

The source of these data is the Chennai Municipal Corporation. This is also the average of three years of data on the BPL families in the city, as a proportion of the number of households estimated for the three years, 2007/08 to 2009/10. 
areas in Chennai was sampled to understand their contribution to the urban economies where they are located.

The sample size, based on the assumption of 14 per cent urban poor population in Chennai, with a 10 per cent error or a 90 per cent confidence interval, turns out to be 615 . This is based on the following equation (1):

$$
N=\frac{Q}{P} \times \frac{1}{e^{2}}
$$

where $\mathrm{P}=14 ; \mathrm{Q}=86 ; \mathrm{e}=0.10 ; \mathrm{N}=614$.

As 14 per cent urban poor are used in some of the computations to assess their contribution, it turns out that the sample size of 1,200 (of 1,000 households and 200 enterprises) for this study allows for a 0.01 error (or a 99 per cent confidence level). ${ }^{3}$

Some 1,000 households and 200 enterprises in the slums of Chennai were sampled. If the data using descriptive statistics, namely mean or frequencies, were analysed, then nearly any sample size will suffice. However, given that more in-depth analysis, such as multiple regression, probit analysis, and use city-wide aggregation is being used, a large size sample is needed and hence is envisaged.

\section{Sampling design}

In Chennai, several areas where the slums are concentrated in the city were selected. A geographically representative sampling, using a map of the slums of Chennai obtained from the Tamil Nadu Slum Clearance Board (TNSCB) was used to sample a subset of the slums and then to select households within those slums. Some 1,000 households and 200 informal enterprises were covered to get a large enough number for doing econometric work as well as to perform city-wide aggregation.

Based on the list obtained from TNSCB, Chennai has 1,677 slums, taking into account notified and non-notified areas. Some 50 slums and 20 households were selected to account for a sample size of 1,000 households, based on a map of the city's slums we received from TNSCB. To select the 20 households within the selected slums, every fifth house in smaller slums and every tenth house in larger slums using the right hand rule was selected. Also a list of tenements (from TNSCB) made it possible to complete city-wide aggregations.

This was obtained by using equation (1) substituting for $P=14, Q=86$ (which is 1-P), and 1,200 for $\mathrm{N}$, solving for $\mathrm{e}$. 
To cover 200 informal enterprises, four enterprises from each of the 50 selected slums were selected, implicitly taking into account the criterion that different categories of enterprises need to be represented for detailed analysis used to estimate their contribution. In the surveys, a full headcount of all enterprises in the selected slums was carried out to enable extrapolation of the sampled data to all the enterprises in the slums.

\section{How was the contribution of the slums to the city economy assessed?}

To assess the contribution of the slums to the city's economy, the factor income approach was applied. This approach is typically used in national income accounting. Based on this method, data on incomes in the slums generated from the household surveys were obtained. ${ }^{4}$ The average household monthly gross income was converted into per capita income and annual figures for the slums, based on the number of poor families given in the information from TNSCB. This was then converted to total income for the poor population, based on the average family size from our primary surveys.

Next, information obtained on the average gross profits of enterprises, which they stated after making their income net of salaries, rents and raw material costs was used to compute a total gross profit based on the number of enterprises in each slum, which was obtained simultaneously through a headcount of enterprises in the selected 50 slums. Total enterprise profits for all the slums in the city were computed based on the assumption that the number of enterprises in each slum would be the average of what we found, based on a sample of slums. For the slums that were surveyed for the headcount of enterprises, the actual total number of enterprises that was found there was used. The monthly average gross profits of the enterprises were converted to annual numbers and then were cumulated to represent the contribution of the enterprises.

Furthermore, to estimate the contribution of the slums in relation to the city economy, an estimate of the city economy was needed. For this, the district's ${ }^{5}$ GDP, which is a unique data set published by most of the states (and is available at the Planning Commission's website: www.planningcommission.nic.in/plans/stateplan/ index.php?state=ssphdbody.htm), was used.

In this, the chief wage earner respondents were asked about their seasonal income, if any, and added that to the permanent income reported. However, only 1 per cent of the respondents reported having seasonal income.

5 In the case of Chennai, it has already been noted that the district and the metropolitan area is concomitant. 
An explanation of how the income of Chennai was computed, is in order. The ratio of the gross district domestic product (GDDP) of Chennai in current prices to the GDDP in constant 1999/2000 prices, both for 2005 and 2006 was used. This provided the price index over $1999 / 2000$ to $2005 / 06$. This ratio was applied to GDDP of Chennai for 2005/06 (in current prices) to arrive at the GDDP of Chennai for 2011/12 in current prices (as the contribution estimates are in current prices for 2011/12). Computed in this way, the GDDP of Chennai in current prices for 2011/12 was obtained. Then, the ratio of the contribution of the slums to the GDDP (in current prices) was used to arrive at the poor's contribution to the city economy.

Specifically, this paper intends to understand the contribution of the urban poor to the economy. In this attempt, the impact of various sociodemographic and economic characteristics of the urban poor on their ability to contribute to the economy (measured by income) also must be understood. The equations used to understand the impact of various characteristics of the urban poor on their economic contribution, are to be derived from the micro, household-level data gathered through the primary surveys. ${ }^{6}$

For this study, it had been hypothesized that the economic contributions made by the urban poor may be specified and explained by the following equation:

Income of urban poor resident $\mathrm{t}_{\mathrm{i}} \mathrm{a}_{0 \mathrm{i}}+\mathrm{a}_{1 \mathrm{i}}$ age $+\mathrm{a}_{2 \mathrm{i}}$ education $+\mathrm{a}_{3 \mathrm{i}}$ occupation $+a_{4 i}$ migrant status $+a_{5 i}$ dummy for salaried $+a_{6 i}$ social group $+a_{7 i}$ gender $+e_{i}$

The income of the urban poor resident in equation (2) is a variable that indicates the economic contribution of the urban poor resident $\mathrm{i}$, and is measured by the sum total of wages, taxes paid, savings, and capital formation (reflected in assets). This is dependent on the sociodemographic characteristics of the poor, such as their age, education, occupation, migrant status, social group (whether SC/ST or not), ${ }^{7}$ gender and salary status. Specifically, it is assumed that the higher their education, the more skilled their occupation, the younger their age, the more they contribute to the city economy. Also, the salaried contribute more to the city economy.

Equation (2) is estimated by ordinary least squares. It should be noted that the data that form the basis for estimating equation (2) are micro, individual level (as denoted by the subscript $i$ in the equations) and are invaluable in enabling our assessment of their contributions.

6 The survey instruments used for households and enterprises are available upon request.

7 SC stands for scheduled caste; ST stands for scheduled tribe. 


\section{Hypotheses}

All data cannot be captured quantitatively. Qualitatively, certain hypotheses are tested with respect to the role and contribution of the urban poor to the urban and national economy, based on the micro, household-level data. They are as follows:

1. Given the role of the urban poor as domestic and construction workers, it is hypothesized that low income areas contribute to the service sectors rather than manufacturing sectors of the urban economies where they are located. Examination of the occupational distribution of the urban poor reflects the supply of the labour force to the urban centre. In India, the urban poor contribute workers to the civil construction sector, drivers, domestic servants and many of the unskilled labour force of the urban centre. Thus, the low income areas export a product, unskilled and semiskilled labor services for which there is relatively inelastic demand, whose price tends to be low and are also readily substitutable.

2. Low income areas contribute to the rural economy through their remittances. This hypothesis follows from earlier work on migration from rural to urban areas. Related literature shows that rural-urban or circular migration leads to the sending of remittances to marginalized sending localities, which can be used to invest in human capital or in productive assets in sending localities and can play an important role in reducing vulnerability, improving food security, stimulating land markets in sending areas, increasing local wages and the demand for local goods and services and generally improving the economy (Deshingkar, 2006).

3. The next hypothesis is that the informal enterprises in the low income areas source their funds from internal savings rather than through banks or other financial institutions. It is possible that microcredit is also active in the low income areas. ${ }^{8}$ Nobel laureate Mohammad Yunus, the founder of Grameen Bank in Bangladesh and the father of microfinance, reckons that 5 per cent of the bank's clients exit poverty each year. Yet economists point out that there are surprisingly few credible estimates of the extent to which microcredit actually reduces poverty. Thus, it is assumed that the urban poor contribute to the urban centre through their own savings.

Microcredit involves providing unsecured small loans to poor people in developing countries whom most banks would turn away. Yet, those small borrowers almost always repay their loans (and the fairly steep interest charges) on time, which suggests that they find productive uses for the money. Available from www.economist.com/PrinterFriendly.cfm?story_id=14031284. 
4. The urban poor contribute to public revenues through payment of property and other taxes, given that there is some value to their dwelling and also because their economic activity might add value that is taxable;

5. The slum dwellers contribute to a more skilled future labour force of the urban and national economy as their children are likely to be more educated than them.

Summarizing, the methodology for this study consists of quantitative techniques, such as multiple regression and probit analysis for the city of study, Chennai, based on the rich microlevel data, the extrapolation of the slum-level and enterprise-level data to all slums and the city economy, using standard national income accounting methods combined with qualitative testing of other hypotheses that have been made regarding the contribution of the urban poor to the city's economy.

\section{Occupational distribution}

The sample consisted of 1,000 households and 200 enterprises in the slums of Chennai. Nearly 85 per cent of the sample of respondents had a secondary education or less. Most (84 per cent) were married. Nearly 40 per cent lived in reinforced cement concrete (RCC) houses, while more than two-thirds (38 per cent) of the respondents were in houses constructed with asbestos or zinc sheets. About one fifth resided in thatched houses. ${ }^{9}$

Table 1 describes the occupational distribution of the urban poor in the labour force along with their average monthly income. Consistent with the hypothesis, the table confirms that the occupational distribution of the slum dwellers in Chennai is skewed towards services, such as driving, construction work, manual labour and services in private organizations. More than half of the respondents worked in services, such as those mentioned above. Other significant occupations were cooks, domestic work and mechanics. In addition, the average monthly income for those employed in government was the highest (at 13,070 Indian rupees (Rs) (\$204)), followed by hospital workers at Rs9,600. About 10 per cent of the respondents reported that their income had increased over the last two years. Almost all (99 per cent) slum dwellers had television sets and one fifth had a two-wheeler. The largest component of the urban poor's expenditure was on food, followed by rent. Less than one fifth of the respondents borrowed to finance their additional expenditure and those that did, borrowed an average of Rs2,687 a month.

9 Characteristics on which relevant data were available for non-slum households in Chennai were compared, using secondary data, in a separate section later. 
Table 1. Occupational distribution of the urban poor

\begin{tabular}{lcccc}
\hline \multicolumn{1}{c}{ Occupation } & $\begin{array}{c}\text { Number of } \\
\text { respondents }\end{array}$ & Percentage & $\begin{array}{c}\text { Standard } \\
\text { deviation }\end{array}$ & $\begin{array}{c}\text { Average monthly } \\
\text { income (in Rs) }\end{array}$ \\
\hline Factory worker & 37 & 3.7 & 2401.2 & 7608.1 \\
Self-employed & 140 & 14.0 & 4498.2 & 8280.0 \\
Driver & 159 & 15.9 & 3071.3 & 8437.1 \\
Mechanic & 43 & 4.3 & 3558.3 & 8569.8 \\
Pensioner & 5 & 0.5 & 4324.3 & 8800.0 \\
Private organization & 102 & 10.2 & 6540.8 & 9553.9 \\
Hospital worker & 5 & 0.5 & 4615.2 & 9600.0 \\
Government service & 35 & 3.5 & 7069.1 & 13071.4 \\
\hline Total & $\mathbf{1 0 0 1}$ & $\mathbf{1 0 0 . 0}$ & $\mathbf{4 0 8 7 . 6}$ & $\mathbf{7 8 7 4 . 3}$ \\
\hline
\end{tabular}

Overall, 39 per cent of the respondents were working within the same slum. The average distance of the work place for the chief wage earner was 7.8 kilometres. While a small proportion (16 per cent) had a two-wheeler, which they used to get to their place of work, more than one third of the respondents reached their place of work by foot. This shows the need for pedestrian-friendly cities, especially for the urban poor, marginalized and the vulnerable. An additional one fourth of respondents took a bus to get to work. Nearly 94 per cent had a mobile phone, which testifies to the ease with which feedback can be solicited on various programmers targeted at them.

Based on the sample, the supply of drivers, cooks, maids and labourers from the slum to the city economy can be estimated consistent with the hypothesis that the slums supply unskilled labour to the city economy. The sample consisted of 1,000 households with an average family size of 3.83 , and an average worker size of 1.19 for every family of 3.83 members. Hence, a total population in the labour force of $1,190(1,000 \times 1.19)$ is covered. The total number of construction workers, drivers, labourers, domestic workers and cooks in the sample is, respectively, 165, 159, 112, 68 and 28. If it is assumed that there were 165 construction workers for every 1,190 in the city's labour force, then for the 380,800 poor labour force living in the slums, the total supply of construction workers, drivers, labourers, domestic workers and cooks, respectively, would be $52,800,50,880,35,840,21,760$, and 8,960 to the city from the slums.

The hypothesis as to whether or not low income areas contribute to remittances is rejected. This is because a small proportion (10 per cent) of the slums 
of Chennai is migrant based on the sample. ${ }^{10}$ Of them, only 1.2 per cent (12 in actual numbers) were sending remittances to their place of origin, the average amount of the monthly remittance being Rs1,792.

The next hypothesis that the informal enterprises in the low income areas source their funds from internal savings rather than through banks or other financial institutions is well-founded. Based on the survey of informal enterprises, it appears that while 80 per cent of the enterprises used their own savings to start the enterprise, an additional 18 per cent of enterprises took loans from family, relatives and friends. Only 2 per cent of the surveyed enterprises approached a bank, pawnbroker or a microfinance institution while starting their business.

Taking the next hypothesis that the urban poor contribute to public revenues through payment of property taxes, given that there is some value to their dwelling, the results show that 45 per cent of the households that were surveyed in the slums lived in their own dwelling built by themselves. Nearly one third (32 per cent) of property owners paid property tax, the average amount of the property tax being Rs693, with a maximum of Rs6,400 in one case. Sometimes, the property tax they paid for the current year included arrears from previous years. For the 266 payers, the total amount of tax paid was Rs184,327. It was found that the respondents paid on average Rs1,378 to the Tamil Nadu State Marketing Corporation to purchase alcoholic beverages, for a total revenue of Rs705,650, for 1,000 respondents. This is consistent with evidence from a study by Gupta, Arnold and Lhungdim (2009), which indicated that Chennai had the highest rates of alcohol consumption and domestic violence, among the eight large Indian cities that were studied. ${ }^{11}$

While the urban poor may be contributing to the state and local economy through the payment of indirect taxes as well, the respondents were not questioned about indirect taxes as these are included in commodity and service taxes, and are largely sourced out of their income. Including their income as well as these indirect taxes in their contribution to the urban economy would represent double counting.

The other hypothesis is that slum dwellers contribute to a more skilled future labour force of the urban and national economy as their children are likely to be more educated than them. The profile of the children of the slum dwellers in the school going age group was examined. On average, one third of the children in the families,

10 While in Sridhar and Reddy (2014), a migrant is defined as anyone who moved to the city in the last 10 years, in this paper, we allowed the chief wage earner to make a decision regarding whether or not $\mathrm{s} /$ he is a migrant or a native resident of the city.

11 This report analyses health and living conditions in eight large Indian cities (Chennai, Delhi, Hyderabad, Indore, Kolkata, Meerut, Mumbai, and Nagpur). 
were out of school. ${ }^{12}$ It was found that 48 per cent of children of slum dwellers were going to government schools, whereas 38 per cent were going to private schools. Of those who were going to government schools, most of them (96 per cent) were getting free books, more than two third free uniforms and another one fifth were getting scholarships and midday meals. A majority (95 per cent) of the poor surveyed financed their children's education through their own savings. ${ }^{13}$ Hence, there is every reason to believe that the slums contribute to a more skilled future labour force of the urban and national economy as their children are likely to be more educated than them.

\section{RESULTS FROM ESTIMATION}

Equation (2) was estimated to understand the determinants of the contribution of the urban poor to the economy, as discussed earlier.

Table 2 summarizes the regression from the income regression, which is estimated by ordinary least squares. Gender, education level and the salary status of the respondent were found to have a significant impact on income. Males contribute on average nearly Rs1,900 more per month than their women counterparts. The poor with a higher level of schooling completed, such as primary, secondary, high school, college and so forth, earn about Rs 400 more. The salaried poor contribute nearly Rs2,350 more per month than their self-employed or other non-salaried counterparts. The model as a whole explains 11 per cent of income of the urban poor. ${ }^{14}$

While the regression summarized in table 2 is based on the individual respondent's earning, table 3 summarizes the household income and expenditure, based on the sample. An attempt was made to reconcile these estimates with other available sources that publish the data.

There are no readily available estimates of income, but other comparable estimates of expenditure based on data from the National Sample Survey Organization exist. Chaudhuri and Gupta (2009), based on the National Sample

\footnotetext{
12 This was the result of computing the proportion of children out of school based on the total number of children who were reported to be going to either a government or private school and the total in the school going age group (6-18 years of age).

13 As far as the financing of health needs (may or may not be related to children's health) is concerned, it was found that nearly (90 per cent) had no health insurance, and a majority depended on their own savings (85 per cent) and loans from relatives and friends for health needs (17 per cent).

14 A conceptual framework for the regressions has not been presented as there is a lengthy stream of literature which has estimated such wage equations.
} 
Table 2. Determinants of income of the urban poor

\begin{tabular}{|c|c|c|c|c|}
\hline Variable & Coefficient & $\begin{array}{l}\text { Standard } \\
\text { error }\end{array}$ & $\mathbf{t}$ & Mean \\
\hline (Constant) & $4359.20^{\star \star \star}$ & 707.12 & 6.16 & \\
\hline Gender & $1902.36^{\star \star \star}$ & 387.68 & 4.91 & $88 \%$ (male) \\
\hline Age & 7.72 & 11.77 & 0.66 & 41 years \\
\hline Education & $398.81^{* \star \star}$ & 56.88 & 7.01 & $\begin{array}{l}4 \text { (middle school } \\
\text { completed) }\end{array}$ \\
\hline $\begin{array}{l}\text { Dummy for salaried } \\
\text { versus non-salaried }\end{array}$ & $2347.34^{\star \star \star}$ & 474.53 & 4.95 & $7 \%$ (salaried) \\
\hline Caste & -398.61 & 246.81 & -1.62 & $53 \%$ (SC/ST) \\
\hline Dummy for migrant & 241.60 & 419.09 & 0.58 & $9 \%$ (migrant) \\
\hline
\end{tabular}

Dependent variable: Income of the chief wage earner in the previous month (gross).

Mean: Rs7,904.8.

Number of observations: 999.

Adjusted R-squared: 0.11.

Note: $\quad{ }^{* \star}$ Statistically significant at the 1 per cent level.

Table 3. Distribution of household income and expenditure in the slums of Chennai

\begin{tabular}{lccccc}
\hline & Mean & Minimum & Maximum & $\begin{array}{c}\text { Standard } \\
\text { deviation }\end{array}$ & N \\
\hline $\begin{array}{l}\text { Chief wage earner's previous } \\
\text { month earning (gross) }\end{array}$ & 7904.80 & 1500 & 50000 & 4085.66 & 1001 \\
$\begin{array}{l}\text { Household's previous month } \\
\text { earning (gross) }\end{array}$ & 9329.00 & 1500 & 71000 & 5580 & 1001 \\
$\begin{array}{l}\text { Household's previous month } \\
\text { expenditure }\end{array}$ & 8063.83 & 1500 & 35000 & 3554.57 & 999 \\
\hline
\end{tabular}

Survey (NSS) sixty-first round survey (2004/05), present a summary mapping, of best and worst districts within each state in terms of average monthly per capita expenditure (MPCE) or poverty (head count ratio (HCR)), to indicate the spatial disparity among the districts within and across the states. They (in table 7 of their report) find that in Chennai (their "best" MPCE district, whose area is actually concomitant with the municipal corporation) the poor's average MPCE was Rs1,596. We note that while their data were from 2004/05, the primary surveys for this paper were completed in 2012, hence the average MPCE of Rs2,105 we obtain here (total 
monthly household expenditure of Rs8,063.83 reported in table 3, divided by the mean household size of 3.83 members, based on the surveys, is Rs2,105.44), is consistent with the NSS data from 2004/05 reported by Chaudhuri and Gupta (2009).

Based on the estimates of income and expenditure in table 3, the magnitude of savings is determined. This has implications for capital formation in the economy at large. Based on table 3, on average, the household's savings are roughly Rs1,265.17. This is expected to translate to capital formation in the economy as they become capital in the form of deposits in banks (35 per cent of our respondents said that they had a bank account), chit funds or revolve in self-help groups, and eventually become loans to some other activity. While 25 per cent of our respondents reported that they were saving, based on the stated household income and expenditure, only 7 per cent of the respondents were actually saving! We also computed to find that 75 per cent of the sample had a per capita income of less than or equal to $\$ 2$ a day, hence they are the genuinely poor.

In the following brief subsection, characteristics on which data were available for the slum and non-slum residents of the city are compared.

\section{INEQUALITIES BETWEEN THE SLUM ECONOMY AND THE NON-SLUM ECONOMY}

The information in this section is necessarily anecdotal and is qualitative. Quantitative data have been presented and compared only for those characteristics for which similar information was available from secondary sources.

With respect to the quality of housing, 22 per cent of the surveyed slum households had thatched houses (deemed to be of poor quality). As per Agarwal (2011), this was 18 per cent (based on data from 2009) for the slum households in Chennai. As per the study by Agarwal (2011), the analogous percentage of households in houses built with poor quality materials in non-slum areas of the city was less than 10 per cent, but was well above 45 per cent in the case of the poorest households.

Gaur, Keshri and Joe (2013) cited some interesting health outcomes with respect to inequalities between the slum economy and the non-slum economy in Chennai. They found that Chennai (along with Hyderabad) showed a high prevalence of overweight women across both slum and non-slum areas. The intensity of incomerelated inequalities in underweight outcome was much greater for non-slum areas, whereas inequalities in overweight outcomes were higher among slums. 
The findings on disparities between the slums, non-slums, the poor living outside of the slums, and in comparison with other studies point towards a need for better counting of the proportion of disadvantaged city dwellers, and more focused efforts to reach the large segment of the urban poor who suffer sharp disparities in terms of various indicators.

\section{Profile of enterprises}

On average, there were 25 enterprises in each slum, as described earlier based on a headcount of enterprises. Less than one fifth of the enterprises were headed by women and half of them were owned by the young (up to the age group of 40). Also 88 per cent of them were owned by Hindus, with the remaining equally owned by Muslims and Christians.

A review of the education of the owners of the enterprises indicated that 29 per cent of them had completed middle school and one fifth had completed secondary school; only about 3 per cent were graduates and 2 per cent had an ITI or technical diploma. Surprisingly, about 17 per cent were illiterate. All in all, the findings show that education is not a decisive factor for running microenterprises in the slums.

The profile of the enterprises in the slums as shown in table 6 reveals that about 67 per cent of the enterprises belong to the food (eat-in and take away types), beverages or grocery store related sectors, and slightly less than one third belong to the service sector, such as saloon, tailoring and mobile recharge. The highest average profit per enterprise is in the steel and engineering sector.

Table 6. Profile of enterprises, Chennai's slums

\begin{tabular}{lcccc}
\hline Industry sector & $\begin{array}{c}\text { Number of } \\
\text { enterprises }\end{array}$ & Percentage & $\begin{array}{c}\text { Average monthly } \\
\text { income from sale } \\
\text { (in Rs) }\end{array}$ & $\begin{array}{c}\text { Average surplus } \\
\text { earned in } \\
\text { a month (in Rs) }\end{array}$ \\
\hline Food & 56 & 28.0 & 30526.8 & 8098.2 \\
Groceries & 78 & 39.0 & 25464.1 & 6331.8 \\
Service & 47 & 23.5 & 28010.6 & 7095.7 \\
Repair work & 13 & 6.5 & 22692.3 & 8769.2 \\
Steel and engineering & 2 & 1.0 & 50000.0 & 16625.0 \\
Furniture \& wood work & 2 & 1.0 & 57500.0 & 10000.0 \\
Leather work & 2 & 1.0 & 45000.0 & 14000.0 \\
\hline Total & $\mathbf{2 0 0}$ & $\mathbf{1 0 0 . 0}$ & $\mathbf{2 8 ~ 0 6 1 . 0}$ & $\mathbf{7 3 8 0 . 7}$ \\
\hline
\end{tabular}


Three fourths of enterprises in the sample started after 2000, with most of them being individually owned and 3 per cent of them being partnerships. On average, their investment in fixed assets was Rs53,700. About 87 per cent of the enterprises served residents of the same slum, while only 7 per cent served different locations within the city. On average, the daily customers of those enterprises increased from 38 to 78 since the time they started, although 51 per cent said that there were other competitors selling the same products.

Table 7 summarizes income and surplus earned from the sale of the enterprises and their costs in the form of rent, raw material, transport, utilities and the salaries paid. As shown in table 7, the average overall surplus earned by the enterprises after deducting their costs is Rs7,381 per month.

Table 7. Enterprise profits and costs

\begin{tabular}{lrrrrr}
\hline & Mean & Minimum & Maximum & $\begin{array}{c}\text { Standard } \\
\text { deviation }\end{array}$ & N \\
\hline Enterprise income from sales & 28061.0 & 3000 & 150000 & 25525.5 & 200 \\
Enterprise overall surplus earned & 7380.7 & -5000 & 70000 & 6112.3 & 200 \\
Amount spent on rent & 2880.3 & 200 & 20000 & 2341.0 & 94 \\
Amount spent on raw materials & 14024.1 & 50 & 100000 & 16291.6 & 193 \\
Amount spent on transport & 1758.9 & 100 & 60000 & 5180.7 & 146 \\
Amount spent on electricity bill & 1016.3 & 100 & 15000 & 1381.5 & 142 \\
Lowest salary paid & 4220.7 & 1500 & 8000 & 1685.4 & 58 \\
Highest salary paid & 4737.9 & 1500 & 10000 & 1927.0 & 58 \\
Total amount paid as salaries & 6763.8 & 1500 & 35000 & 5620.2 & 58 \\
\hline
\end{tabular}

One grocery enterprise sampled was running at a loss and three others were breaking even (which indicates hope that the enterprise may turn a profit in the near future). The majority (70 per cent) of the enterprises were self-maintained and operated (by employing themselves and/or immediate members of their family), more than 27 per cent of them employed only one worker (apart from themselves or their immediate family) and 3 per cent of them employed three workers. More than three fourths of the workers in those enterprises were from the same slum. This shows that the enterprises established in the slums are providing job opportunities for the local economy.

On average, the total amount of salary paid was Rs6,764. About 41 per cent of the owners were running the enterprise on their own land, 14 per cent were operating on public land and the remaining were paying rent. The average amount of rent paid 
was Rs 2,880 . On average, the enterprises spent Rs 14,024 to purchase raw materials during the previous month.

To start the enterprise, 80 per cent of the enterprises used their own savings. A surprising finding was that few (4 per cent) of the enterprises approached a bank for a loan. Among those who approached a bank (8 out of 200), only one enterprise was granted a loan. The reasons given by the banks for not granting loans were lack of adequate security and lack of evidence of address required as part of their Know Your Customer (KYC) norms. About one third of the operators of the enterprises received some training before they started their business.

More than one fourth of the operators used sources other than banks for taking a loan to run their enterprise. Three fourths of them approached either a moneylender or pawnbroker. A little more than one fifth of them approached friends and relatives. Less than 2 per cent of them approached microfinance institutions for the loans.

About 48 per cent of the enterprises have expanded since they opened, while 11 per cent of have downsized due to lack of demand for their services/products. Of those that expanded, an additional investment was made in 87 per cent of them and in less than one fifth of them, additional jobs were created. Interestingly nearly three fourths of the 200 enterprise owners surveyed were optimistic about the prospects for their enterprise, consistent with the fact that several of them were continuing even though they were just breaking even.

\section{CONTRIBUTION OF THE SLUMS OF CHENNAI TO THE CITY ECONOMY}

Using the method described in the section on methodology, the contribution of the households and enterprises to the city's economy was derived. Using the estimates of TNSCB, the number of slums in the city, estimates of their contribution, taking into account incomes earned by the households, and gross profits (before tax) earned by enterprises (net of salaries paid, raw material costs and rents paid) were made. Assuming that there are 1,677 slums in Chennai, then taking into account the above components, the slums which constitute 19 per cent of the city's population, ${ }^{15}$ contribute 14 per cent to the city economy (the non-agricultural GDDP of Chennai in

\footnotetext{
15 The population of the Chennai Municipal Corporation, according to the 2011 census is $4,681,087$. When taking into account the extended city corporation area (after the merging of surrounding corporations), the city corporation's area is 6,612,937. The number of poor families in the city as provided by the Tamil Nadu Slum Clearance Board is 320,000 . The city's poor population, based on an assumption of 3.83 members per family (based on the survey), is 1,225,600, and accounts for 18.53 per cent of the city's population.
} 
current prices for 2011/12 was computed to be Rs302 billion), or Rs41.97 billion (of which Rs38.28 billion is contributed by household income and Rs 3.68 billion by enterprises). This indicates that 19 per cent of the city's population contributes to nearly 14 per cent of the city's economy, which is not a negligible amount. Table 8 summarizes the contribution made by households and enterprises to the economy of Chennai.

Table 8. Contribution of slums to Chennai's economy***

\begin{tabular}{lcc}
\hline & \multicolumn{2}{c}{$\begin{array}{c}\text { Number of slums=1 677 } \\
\text { (19\% of city's population) }\end{array}$} \\
\cline { 2 - 3 } & Contribution (in INR) & \% to city economy \\
\hline Gross income & 38283135744 & 12.68 \\
Value added by enterprises (includes rent) & 3683736893 & 1.22 \\
\hline Total & $\mathbf{4 1 9 6 6 ~ 8 7 2 ~ 6 3 7}$ & $\mathbf{1 3 . 9 0}$ \\
\hline Note: & ${ }^{* * * 19}$ per cent of the city's population contributes 14 per cent of the city's economy.
\end{tabular}

These estimates were compared with estimates for Bengaluru (Sridhar and Reddy, 2014), where it was found that 15 per cent of the city's poor population contributed to 3-3.5 per cent of the city's economy. Thus, in Bengaluru, the slum dwellers constituted not only a smaller proportion of the city's population as compared with Chennai, but they also contributed a significantly smaller proportion to the city economy. There are several reasons for the different findings across these two Indian cities, including:

1. Chennai is smaller than Bengaluru, with a population of 6.6 million (which is the extended area of the Chennai corporation of 429 sq.km after the merger of the surrounding areas into the Chennai corporation limits in September 2011, following the census count), compared with the Bengaluru population of 8.43 million. However, the number of poor people living in Chennai compared with Bengaluru is greater; they constitute 18.53 per cent of the city economy, as compared with 15 per cent in Bengaluru.

2. The non-agricultural GDDP (in current prices) of Chennai, Kanchi and Tiruvallur districts (all of which are part of the extended Chennai

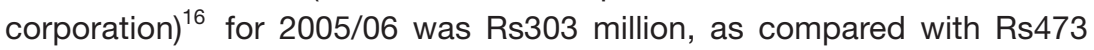

16 The total GDDP for Chennai and half of each of the other two districts (Kanchi and Thiruvallur), all in current prices, for 2005/06, were considered. 
million for Bengaluru. The smaller number in Chennai could be the result of underreporting, a variable over which the researcher has no direct control. Based on discussions with the Tamil Nadu Directorate of Economics and Statistics a possible explanation for this is that in Chennai, most of the manufacturing that contributes to the city's GDP is beyond the city corporation boundaries, while in Bengaluru, the high contributors to the city's GDP, the IT industries, are located very within the city boundaries.

3. In addition, a review of the per capita incomes of Chennai (along with that of Kanchi and Thiruvallur districts, as they are also part of the extended Chennai corporation), and that of Bengaluru showed that the average annual per capita income of the Chennai slums (where surveys were conducted) was Rs31,236 as compared with Rs16,844 for the Bengaluru slums. ${ }^{17}$ The review of the incomes of the urban poor indicated that there was significant under-reporting of income of the urban poor in Bengaluru in comparison with those in Chennai, for the same occupations (for example, a driver in Bengaluru reportedly earns on average only Rs5,550, whereas a driver in Chennai earns Rs8,437 on average, both based on the surveys). This could be partly due to the fact that the government of Tamil Nadu is quite generous as far as worker salaries are concerned. For instance, a driver in Tamil Nadu who has about 13 years of work experience in government, earns about Rs 24,000 a month, based on the surveys, whereas the maximum income of a driver with eight years of experience Bengaluru was only Rs10,000. This is also consistent with the data in the India Labour Report (TeamLease and IIJT, 2009, table B: State wise minimum wages), which shows that minimum wages in Tamil Nadu are Rs91 a day, compared to only Rs88 in Karnataka.

4. The findings indicated that the enterprises contribute to 1.2 per cent of the total contribution of the slums to the city economy in Chennai, as compared with only 0.21 per cent in Bengaluru. Thus, while the majority of the contribution to the city economy is made by households in both the cities, the relative contribution of the enterprises is higher in Chennai.

The findings regarding the contribution made by the poor in the Indian cities to their respective city economies are especially relevant because this group of people tends to undergo a lot of hardships in order to earn their livelihood. Mitra (1992) found at the aggregate macrolevel that, with a rise in the residual absorption of labour in the

The average per capita income of Chennai, Kanchi and Thiruvallur districts is Rs40,750, whereas it is Rs69,418 for Bengaluru Urban District. 
informal sector activities that generated meagre earnings, the average consumption expenditure per capita pertaining to the urban areas of the states declined and the poverty ratio increased. Mitra (2010) reported that several of the long-duration migrants and the natives of slums still had a low level of well-being measured by low household income and consumption expenditure per capita, high child-woman ratio and low education and health expenditure per capita, taking the cases of several Indian cities - Jaipur, Ludhiana, Mathura and Ujjain.

\section{POLICY IMPLICATIONS}

Several policy implications emerge from this research. The first and foremost issue of contention is the identification of the urban poor. This is also consistent with the findings in Paul and others (2012). While information on the type of housing structure was available, the authors still think a reliable indicator of poverty might be expenditure, which is being used by the National Sample Survey Organization (NSSO) of India in their household surveys. The consistency of expenditure with that reported by the NSSO for 2004/05, has been confirmed.

The research indicated that a majority of the slum dwellers were receiving various public services, such as water supply (100 per cent, although it was a public tap for half of them), electricity (83 per cent), street lights (93 per cent), roads (92 per cent), drainage (72 per cent), primary health care centres (24 per cent) and government schools (46 per cent). Public toilets and garbage collection were public services less available in slums where these slums were found wanting, as only 22 per cent had access to public toilets and 13 per cent of slum dwellers had access to garbage collection. In fact, Gupta, Arnold and Lhungdim (2009) found that in Chennai (along with other cities such as Delhi, Mumbai, and Kolkata), not even one out of every four slum households used toilet facilities. This implies that there is great potential for policy to influence and incentivize the entry of private service providers into slums.

Having noted the above regarding various public services, 30 per cent of the slum dwellers were found to have a problem with public services, with half of them being drainage related. In addition, two thirds of them approached someone to resolve the problem, nearly 89 per cent did so collectively, but for most (82 per cent), the problems were not resolved. This indicates that the problem with service delivery is primarily not access, but effectiveness and reliability. Service providers also have to be made more accountable and responsive, as very few agreed that the corporators/ councilors have not done anything substantial for the betterment of their locality. 
For purposes of this paper, the population was related to enterprises in the slums (200 firms in 50 enterprises were sampled and a headcount was conducted, which indicated that there was on average 25 enterprises per slum) to examine how well the enterprises catered to the needs of the slum population. This showed that there was an enterprise for every 30 persons on average, taking into account the 50 slums in which a full headcount was done.

Another expected finding is that very few poor households had health insurance, with nearly 85 per cent of them financing their health needs out of their own savings. Given the nature of health and emergency needs, it might be too expensive to finance such costs through private means. One possible approach would be to explore health insurance options and if there is any scope for group welfare schemes for the slum dwellers as a whole. Surprisingly, none of the respondents showed any awareness of the Rashtriya Swasthya Bima Yojana (RSBY), a health insurance scheme for below poverty line families, which was launched in 2007. The objective of RSBY, a programme not specifically targeted at urban areas, is to provide insurance coverage for major health shocks that involve hospitalization.

Another surprising finding is that in the survey of enterprises, a very small proportion (less than 1 per cent) had approached a bank for loan. Most (80 per cent) of the enterprises used their own savings or borrowed money (18 per cent) from family, relatives and friends. However, given the usurious nature of such transactions with pawnbrokers, money lenders and microfinance institutions, the complete bankability of urban areas including slums should be seriously considered.

One of the things as it relates to human capital is that roughly 48 per cent of the children in the surveyed households went to government schools, whereas nearly 38 per cent of children went to private schools. While the urban poor households continue to finance their children's education through their own savings, given the prohibitive costs of private schooling, appropriate investments should be made in government schools, so that the poor can continue to get quality education in government schools.

Finally, given the startling findings in this paper, there may be a case for the Ministry of Housing and Urban Poverty Alleviation, Government of India to replicate this effort in other cities of India in order to not only formulate sustainable policies to support urban poverty reduction, but also to appreciate their contribution to the city and national economies as a whole. 


\section{REFERENCES}

Agarwal, Siddharth (2011). The state of urban health in India: comparing the poorest quartile to the rest of the urban population in selected states and cities. Environment and Urbanization Asia, vol. 23, No. 1, pp. 13-28.

Chaudhuri, Siladitya, and Nivedita Gupta (2009). Levels of living and poverty patterns: a district-wise analysis for India. Economic and Political Weekly, vol. 44, No. 9, pp. 94-110.

Deshingkar, P. (2006). Internal migration, poverty and development in Asia. Briefing Paper, No. 11 (October). London: Overseas Development Institute. Available from www.odi.org.uk/ publications/briefing/bp_internal_migration_oct06.pdf.

Frankenhoff, C.A. (1967). Elements of an economic model for slums in a developing economy. Economic Development and Cultural Change, vol. 16, No. 1, pp. 27-36.

Gaur, K, K. Keshri, and W. Joe (2013). Does living in slums or non-slums influence women's nutritional status? Evidence from Indian mega-cities. Social Science and Medicine, vol. 77 (January), pp. 137-46.

Gupta, Kamla, Fred Arnold, and H. Lhungdim (2009). Health and Living Conditions in Eight Indian Cities. National Family Health Survey (NFHS-3), India, 2005-06. Mumbai: International Institute for Population Sciences; Calverton, Maryland: ICF Macro.

Hayami, Yujiro, A.K. Dikshit, and S.N. Mishra (2006). Waste pickers and collectors in Delhi. Poverty and environment in an urban informal sector. Journal of Development Studies, vol. 42, No. 1, pp. 41-69.

India, Ministry of Housing and Urban Poverty Alleviation (2009). India Urban Poverty Report. New Delhi: Oxford University Press.

Miller, Barbara (2013). Just the Facts 101: Textbook Key Facts. Ventura, CA: Cram 101 Publishing.

Mitra, Arup (1992). Urban poverty: a rural spillover? Indian Economic Review, Special number, pp. 403-419.

(2010). Migration, livelihood and well-being: evidence from Indian city slums. Urban Studies, vol. 47, No. 7, pp. 1371-1390.

Olajoke, Abolade, and others (2013). Contributions of urban informal enterprises to the economy of Ibadan, Nigeria. Global Journal of Human Social Science, vol. 13, No. 5, version 1.0.

Paul, Samuel, and others (2012). The State of Our Cities: Evidence from Karnataka. New Delhi: Oxford University Press.

Sinha, Anushree, N. Sangeeta, and K.A. Siddiqui (1999). Study on the Impact of Alternate Policies on the Economy with Special Reference to the Informal Sectors: A Multisectoral Study. New Delhi: Ford Foundation.

Sridhar, Kala Seetharam, and Nivedita Kashyap (2014). Benchmarking cities: evidence from India. In Urbanization in Asia: Governance, Infrastructure and the Environment, Kala S. Sridhar and Guanghua Wan, eds. New Delhi: Springer.

Sridhar, Kala Seetharam, and A.V. Reddy (2014). Contribution of the urban poor: a pilot study from Bengaluru, India. In Inclusive Urban Planning: State of the Urban Poor Report 2013. New Delhi: Oxford University Press.

TeamLease an IIJT (2009). India Labor Report 2009: The Geographic Mismatch \& A Ranking of Indian States. Bangalore. 
Ulack, Richard (1978). The role of urban squatter settlements. Annals of the Association of American Geographers, vol. 68, No. 4 (December), pp. 535-550.

Vakulabharanam, V., and S. Motiram (2012). Understanding poverty and inequality in urban India since reforms: bringing quantitative and qualitative approaches together. Economic and Political Weekly, vol. 48, No. 47-48, pp. 44. 